\title{
A Curricular Reform Viewed Through Bolman and Deal's Organizational Frames
}

\author{
Lucinda Lyon ${ }^{1}$, Nader Nadershahi ${ }^{2}$, Anders Nattestad ${ }^{3}$, Parag Kachalia ${ }^{4}$, and Dan \\ Hammer ${ }^{5}$
}

\begin{abstract}
Professions exist to serve the needs of society and, in the case of the dental profession, patients. Academic dental institutions strive to help meet these needs by educating and developing future practitioners, educators, researchers, and citizen leaders who serve the community and shape the changing environment in which they provide care. As patient needs, practice patterns, scientific evidence, and economic conditions evolve, dental education must respond with self-assessment and innovation. Guiding any institution through authentic reform requires a number of strategies. Lee Bolman and Terrance Deal suggest four organizational constructs, or frames, through which to observe and navigate a complex organization: Structural, Human Resource, Political and Symbolic. This qualitative case study examines a major curricular reform initiative in a North American school of dentistry through Bolman and Deal's organizational frames.
\end{abstract}

Key words: organizational behavior; organizational change; curricular reform; change management; leadership.

\section{Introduction and Purpose}

Most in health education have little trouble agreeing upon the importance of ongoing curricular improvement to the education of competent practitioners, capable of meeting the diverse needs of the public, well into the future. Confirmation of this assertion can be found in the comprehensive review of dental education, published by the Institute of Medicine (IOM) in 1995, which called for implementation of "an integrated basic and clinical science curriculum that provides clinically relevant education in the basic sciences and scientifically based education in clinical care" (Field MJ, ed.,1995). The American Dental Education Association (ADEA) Commission on Change and Innovation in Dental Education (CCI) was formed in 2005 and charged with development of programs and initiatives to support such reforms (American Dental Education Association Commission on Change and Innovation in Dental Education, 2009).

\footnotetext{
${ }^{1}$ Department of Dental Practice and Community Service, University of the Pacific Arthur A. Dugoni School of Dentistry, $1555^{\text {th }}$ Street, San Francisco, CA, 94103, clyon@pacific.edu

${ }^{2}$ Administration - Office of Academic Affairs, University of the Pacific Arthur A. Dugoni School of Dentistry, nnadershahi@pacific.edu

${ }^{3}$ Department of Oral and Maxillofacial Surgery, University of the Pacific Arthur A. Dugoni School of Dentistry, anattestad@pacific.edu

${ }^{4}$ Department of Integrated Reconstructive Dental Science, University of the Pacific Arthur A. Dugoni School of Dentistry, pkachalia@pacific.edu

${ }^{5}$ At the time this manuscript was written, Dr. Hammer was a student at the University of the Pacific Arthur A. Dugoni School of Dentistry,d_hammer@u.pacific.edu
} 


\section{Problem Statement}

Even with philosophical agreement, initiating and achieving such change can be challenging. The ADEA CCI counts the following factors among those influencing current and future curriculum within each school, "expectations of the parent institution, standing or emerging research foci, strengths among specialty education programs, approaches to clinical education, and pedagogical philosophies and practices" (Haden, et al., 2006).

Shepherding an institution through major curricular reform requires a variety of strategies. Bolman and Deal offer one such strategic tool for looking at situations and organizations through multiple perspectives, or frames. Their widely used frameworks help visualize an organization through four lenses, or perspectives: the Structural, Human Resource, Political, and Symbolic frames. A systematic appraisal of each of these four constructs may help an organization, or institution, capitalize on its strengths, and anticipate potential barriers to success (Bolman \& Deal, 1997).

\section{Research Questions}

The focus of this qualitative study is to retrospectively explore, and better understand, the effect of utilizing these frames, formally and informally, to guide this curricular reform initiative at a North American school of dentistry. A theoretical reflection on the following questions is offered.

1.) Were Bolman and Deal's constructs recognizable and applicable to stakeholders involved in this professional education curricular reform?

2.) How did observation of these organizational frames help leaders understand institutional challenges more clearly?

3.) Did operationally employing these lenses improve leader's ability to address challenges more strategically?

4.) Were Bolman and Deal's frames valuable enough to this process to warrant future use in like change initiatives?

Reflecting on the significance of Bolman and Deal's organizational frames in this particular academic context is appropriately served by case-study (Stake, 1995). Case study is used to gain understanding of a particular experience, within a body of knowledge which, in this study, is the literature on organizational constructs and change. Of Stake's three types of casestudy, the instrumental case study offered authors the most helpful method: to provide insight into an issue or help refine a theory (Stake, 1995).

\section{Background and Theoretical Context}

The School of Dentistry described in this manuscript completed a strategic plan in 2007, which was updated in 2012, with input from a broad range of stakeholders. Educational innovation figured prominently among agreed upon initiatives. The faculty developed a vision for curricular reform, which centered on a commitment to "graduating lifelong learners and critical thinkers able to integrate the science and technology of dentistry." Change would include a greater focus on active integrated learning and critical thinking through the use of multidisciplinary courses and small group case-based learning as a signature andragogy (University of the Pacific Arthur A. Dugoni School of Dentistry School Initiatives, 2007). 


\section{Curricular Change Initiative}

Ensuring a learning environment that encouraged students to integrate content and synthesize solutions to unique, professionally relevant problems, and to demonstrate learning at higher levels than in the past, was critical. Thematically, or topically, integrated curricula was created, with courses taught by interdisciplinary teams that cut across traditional academic boundaries. Principles and techniques associated with evidence-based practice were incorporated. These collective concepts appear to be well endorsed throughout health care professions education (Field MJ, ed.,1995; Hendricson, et al., 2007; American Dental Education Association Commission on Change and Innovation in Dental Education, 2009).

To achieve this integration, the school's curriculum was organized around five thematically related strands: 1.) Integrated Pre-Clinical Technique (IPT); 2.) Integrated Medical Sciences (IMS); 3.) Integrated Clinical Sciences (ICS); Clinical Practice (CP); and 5.) Personalized Instructional Programs (PIP). The aspiration being that students would perceive delivery of these curricular strands as intertwined, coordinated parts of a whole. (Figure 1)

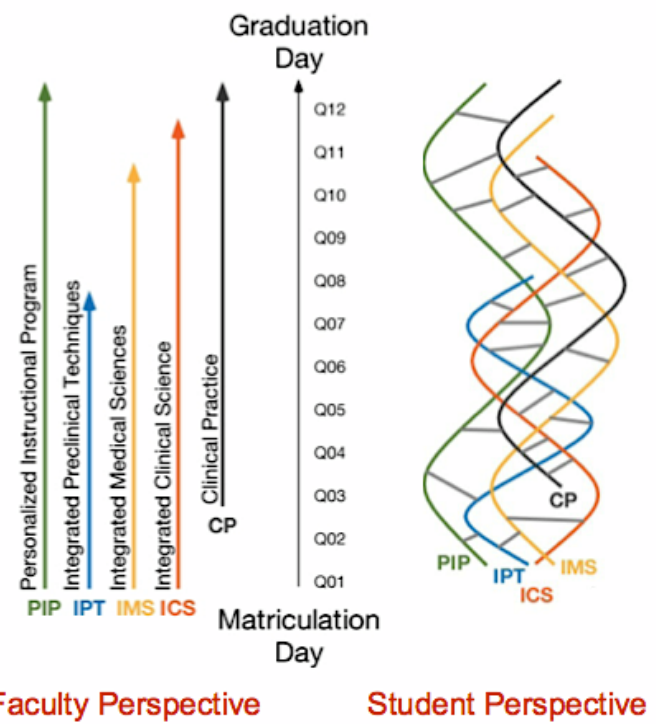

Figure 1. Curricular Strands (Q indicates the twelve quarters of the school's 36 month academic program).

Although unique in its accelerated format, the school's curriculum had historically been fairly traditional. Rather than fully deconstruct and reconstruct the entire curriculum simultaneously, each strand was created and is being refined on its own independent timeline. This revision format was chosen to allow for the highest probability of successful implementation in this institution. To create a unified vision, this model of curricular strands with interconnections was dubbed the Dental Helix Curriculum.

Haden and colleagues report that a number of U.S. dental schools have undergone, or are in the process of, significant curricular change (Haden, et al., 2010). Like many of these institutions, this school's planned revisions included: increased student engagement, increased efficiency of content delivery, and reduction of curricular gaps and unplanned repetition. A more robust learning environment, which encouraged greater critical thinking, was sought (Facione and Facione, 2008). Multi-disciplinary presentation of material in a way that more realistically 
reflected how information is used in clinical practice was an anticipated strength (Irby, 1994). Smaller working groups in both the classroom and clinic were desired to engage students more effectively and provide patients a more personalized experience. Finally, utilization of a greater variety of assessment methods including: cased-based reports and exams, literature reviews, reflective portfolios, and Objective Structured Clinical Examination (OSCE), among others, was believed important (Behar-Horenstein, n.d.)

Initiating and implementing curricular change in dental education can be challenging for many reasons. Bertolami describes the dilemma between graduating "competent practitioners to meet present clinical needs while also preparing students for a radically different kind of practice in the future", a future which includes changes in disease demographics, scientific and technological advances, and patient demands (Bertolami, 2001). Survey respondents from 53 U.S. and Canadian dental schools indicated that "perceived success (it works), compatibility with faculty preferences, faculty comfort, and capacity/feasibility" were primary drivers for their present curricular format (Haden, et al., 2010). To create energy and momentum around change, these paradigms must be challenged and intentional plans made to overcome apprehension and inertia.

Strategies for driving curriculum revision were critical to realizing successful curricular reform in this professional program. Bolman and Deal's organizational frames were understood and used, both formally and informally by a number of leaders within the institution to recognize organizational complexity and approach plans accordingly (Bolman \&Deal, 2003).

\section{Strategy for Driving Change - Bolman and Deal's Organizational Frames}

To help leaders and managers understand their organizations through a variety of lenses, or perspectives, Lee Bolman and Terrance Deal suggest four organizational constructs, or frames: Structural, Human Resource, Political and Symbolic. Each frame includes a set of ideas that help make sense of how individuals and organizations think and work. Individual frames have inherent strengths and weaknesses, advantages and disadvantages, all are founded in both managerial practice and social science research. (Bolman \& Deal, 2003).

Bolman and Deal note that, in the last fifty years, social scientists have devoted considerable energy to the study of organizations to better understand how they work. They advise that their four frames can be described in terms of "central assumptions and propositions" based in this historical organizational research. (Table 1)

The structural frame develops rules, policies, and management hierarchies to coordinate activities. Formal roles or standard operating procedures are designed to align individual, group and organizational effort with institutional goals, available technology, workforce, and environment (Bolman \& Deal, 2003).

The human resource frame assumes that an organization exists to meet human needs and should be customized to the people who populate it. Interplay between the individual and the organization must be strong and positive to achieve reciprocal satisfaction and success (Bolman \& Deal, 2003).

The political frame "views organizations as arenas of scarce resources where power and influence are constantly affecting the allocation of resources among individuals or groups" (Bolman \& Deal, 1985). Power, negotiation and conflict management are ongoing features of this organizational construct. 
Lyon, L., Nadershahi, N., Nattestad, A., Kachalia, P., \& Hammer, D.

Table 1

Overview of Bolman and Deal Four-frame Model

\begin{tabular}{|c|c|c|c|c|}
\hline & \multicolumn{4}{|c|}{ Frame } \\
\hline & Structural & $\begin{array}{l}\text { Human } \\
\text { Resource }\end{array}$ & Political & Symbolic \\
\hline $\begin{array}{l}\text { Metaphor for } \\
\text { organization }\end{array}$ & $\begin{array}{l}\text { Factory or } \\
\text { machine }\end{array}$ & Family & Jungle & $\begin{array}{l}\text { Carnival, temple, } \\
\text { theatre }\end{array}$ \\
\hline Central concepts & $\begin{array}{l}\text { Rules, roles, } \\
\text { goals, policies, } \\
\text { technology, } \\
\text { environment }\end{array}$ & $\begin{array}{l}\text { Needs, skills, } \\
\text { relationships }\end{array}$ & $\begin{array}{l}\text { Power, conflict, } \\
\text { competition, } \\
\text { organizational } \\
\text { politics }\end{array}$ & $\begin{array}{l}\text { Culture, } \\
\text { meaning, } \\
\text { metaphor, ritual, } \\
\text { ceremony, } \\
\text { stories, heroes }\end{array}$ \\
\hline $\begin{array}{l}\text { Image of } \\
\text { leadership }\end{array}$ & $\begin{array}{l}\text { Social } \\
\text { architecture }\end{array}$ & Empowerment & Advocacy & Inspiration \\
\hline $\begin{array}{l}\text { Basic leadership } \\
\text { challenge }\end{array}$ & $\begin{array}{l}\text { Attune structure } \\
\text { to task, } \\
\text { technology, } \\
\text { environment }\end{array}$ & $\begin{array}{l}\text { Align } \\
\text { organizational } \\
\text { and human needs }\end{array}$ & $\begin{array}{l}\text { Develop agenda } \\
\text { and power base }\end{array}$ & $\begin{array}{l}\text { Create faith, } \\
\text { beauty, meaning }\end{array}$ \\
\hline
\end{tabular}

Source: Bolman \& Deal, 2003

The symbolic frame assumes that organizations are bound more tightly by shared values and culture. "Ritual, ceremonies, stories, heroes, and myths" strengthen this collective identity (Bolman \& Deal, 1985). While the structural, human resource, and political frames depend on rationality and linear thought processes, the symbolic frame does not. It assumes that the perception of meanings and values is paramount. An organization's collective history and culture may be most strongly communicated symbolically.

"Each frame is both powerful and coherent. Collectively, they make it possible to reframe, or view the same thing from multiple perspectives" (Bolman \& Deal, 2003). These lenses can be used to better understand an organization, in this case an institution of professional education, and influence its work. Change may be more easily navigated by using multiple frames to gain perspective, diagnose challenges and create strategies for moving forward. No single frame is comprehensive enough to apply to every dynamic, although, "Relatively modest changes in how a problem or decision is framed can have a dramatic impact on how people respond" (Bolman \& Deal, 2003).

\section{Methodology}

Qualitative case study was used to view and determine the significance of both informal and formal use of Bolman and Deal's organizational frames in this academic change initiative. The focus of this examination is appropriately served by case-study, in which the researcher's 
exploration may include examination of a program, activity, process, individual or multiple individuals. The case is bound by time and activity, and detailed information is collected over a sustained period of time (Stake, 1995). Stake offers three forms of case study: the intrinsic case study which focuses on a particular case with no intended interest about other cases or general problem; the instrumental case study aimed at gaining general understanding by studying a particular case and; the collective case study which includes multiple cases rather than a single case. Of these, the instrumental case study offered the most helpful method for this exploration (Stake, 1995). The authors have attempted to understand this case, or particular experience, within a body of literature on organizational constructs and change.

This methodology was used to explore and describe how Bolman and Deal's organizational frames were utilized to help meet challenges associated with a curricular change; to analyze and interpret the effectiveness of this observation and navigation tool; and to reflect on possible generalization or transferability to other such academic reforms. This case represents the experience, challenges, and aspirations of a single academic institution offering professional dental education. Stake notes that qualitative researchers perceive what is happening in key episodes, represent happenings with their own direct interpretation and stories, and use these narratives to help the reader gain experiential understanding of the case. The focus of this methodology may not on the uniqueness of the case, but on what can be learned from it (Stake, 1995).

\section{Participants}

This study is based on a single academic institution, a graduate level professional education program, over a 7 year period of time. During this time, guided by a new strategic plan, the school underwent significant curricular reform. The collective school community consists of an average of 464 students; 460 Faculty (64 full-time; 220 part-time; and 178 volunteer (adjunct)); and 245 Staff.

\section{Data}

Data included observation, collection and review of archival documents and records including strategic plans, progress reports, formative surveys, assessments and inputs; program materials, and annual reports.

Data was analyzed and interpreted first individually and then through a collective iterative process to examine initial outcomes and refine theories and assertions.

\section{Findings}

\section{Structural Frame}

Bolman and Deal define the structural frame as one that focuses on the architecture of organization - management processes, division of labor, coordinating mechanisms, feedback loops, rules and roles, goals and policies - that shape decisions and activities (Bolman and Deal, 2003, Gallos, 2006). Figure 2 is a diagram that demonstrates the overarching structure for the new curriculum, created and discussed at faculty meetings. It includes a summary of the goals or outputs proposed for the reform, including specific learning outcomes and components of the 
school's mission. Also outlined are areas of input that were reviewed to ensure appropriate support and resource structures to achieve successful change.

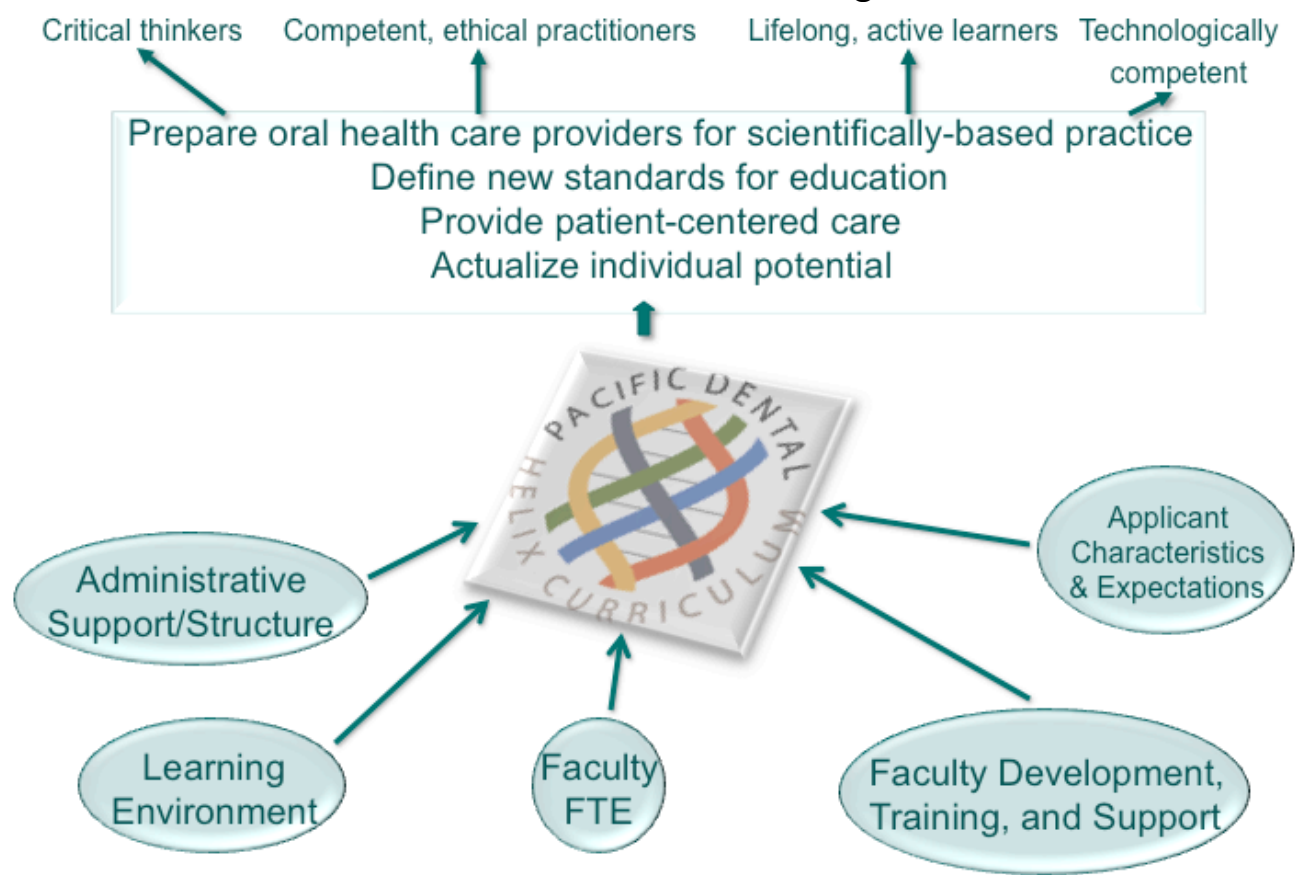

Figure 2. Desired Outcomes and Necessary Inputs of the Dental Helix Curriculum.

Internal stakeholder groups agreed that curricular change should support the school's vision, mission, and values, with specific focus on the following mission-based components: to prepare oral healthcare providers for scientifically based practice, to define new standards for education, and to provide patient centered care, and actualize individual potential (University of the Pacific Arthur A. Dugoni School of Dentistry Mission and Values, 2011). It was also agreed that the new Helix curriculum should produce graduate characteristics to include all current school of dentistry competencies, mapped to reflect ADEA Competencies for the New General Dentist (American Dental Education Association, 2008). These aspirations should focus on graduates who are: critical thinkers, competent and ethical practitioners, lifelong active learners, and technologically competent.

A structure of integrated curricular strands of the Dental Helix Curriculum were stressed versus independent departments and discreet courses. The learner was placed at the center of the structure with thematically related content presented in a way that was appropriate for the student's level of development. Faculty from different disciplines collaborated to organize and develop content. Content coordinators were designated to ensure that the specific content represents current science and is sequenced, delivered, and assessed appropriately. Additionally, coordinators, in their new roles, would support creation of strong links between clinical and biomedical content.

Exploration of necessary inputs for successful change included a review of the current administrative support structure. Resulting structural change included reduction of the curriculum committee from 35 to 12 members, reflecting the Helix strands. The committee's charge moved from a largely operational one to a more strategic one, including responsibility for shaping curriculum; tracking data, assessing outcomes; and supporting new paradigms in teaching and learning. (Figure 3) 


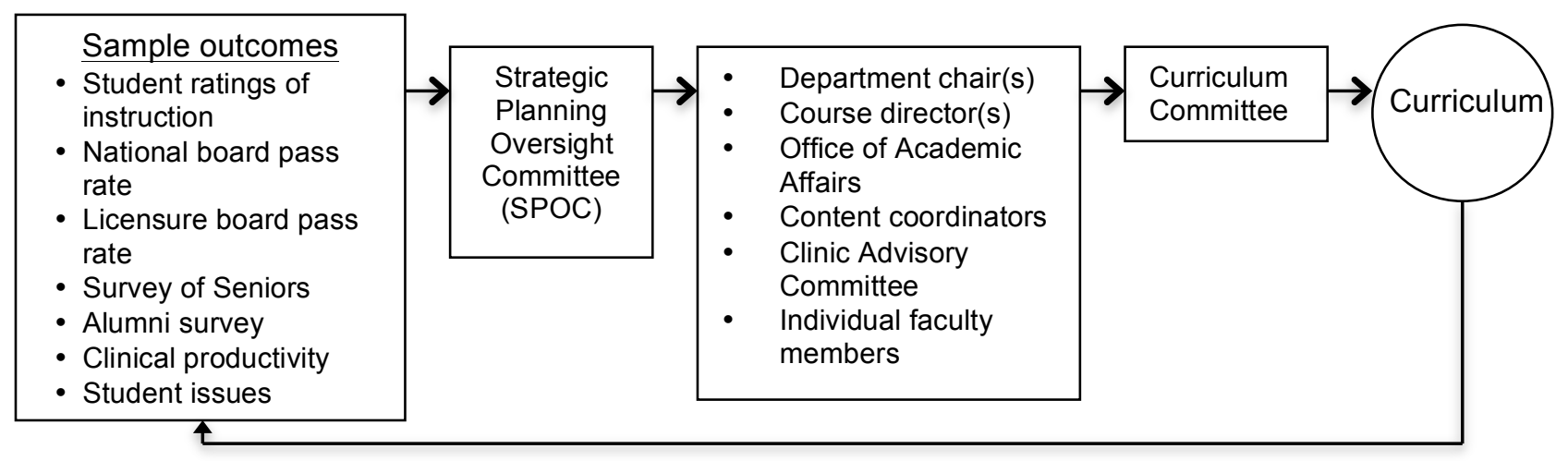

Figure 3. Flow Chart of Course Review Process.

Given that curricular changes focused on an integrated approach, linking content and learning experience from day one to graduation, the student academic performance and promotion review committees were merged into a single, comprehensive committee capable of a more holistic, ongoing review of student's performance. This allowed for earlier recognition of problems, diagnosis, intervention, and remediation.

The school's departmental structure was examined and, through a collaborative process including faculty, chairs, and administrators, departments were merged, reducing the department number from fifteen to eight. This more streamlined structure allowed for increased flexibility, inter-disciplinary collaboration, and integration ease and appears to "accommodate both collective goals and individual differences" as Bolman and Deal allude is possible (Bolman \& Deal, 2003).

The school's physical learning environments were examined with an eye to incorporating new delivery and assessment technologies to support updated learning processes. Through a multiyear feasibility study, the faculty, staff, students, administrators, alumni, and friends of the school of dentistry agreed that, to fully implement new curricular initiatives, the school would need to build an entirely new facility. Although Bolman and Deal stress that "Structures must be designed to fit an organizations circumstances (including its goals, technology, workforce, and environment) (Bolman \& Deal, 2003), it's important to keep in mind that teaching and learning goals should drive design of technology and learning environments, not the reverse. The school's strategic plan, in fact, initiated this exploration in a direction statement to "Optimize our facility assets and technology investments" (University of the Pacific Arthur A. Dugoni School of Dentistry Strategic Plan, 2012).

Faculty roles and resources were evaluated to ensure appropriate full time equivalent (FTE) positions to support more faculty-intensive small group collaborative and case-based learning opportunities in the programmatic strands. A resulting commitment to an increase in faculty FTEs was made with accompanying resources allocated for faculty development. Resources were also reallocated for specialists in Instructional Design and Audiovisual Information Technology to the support deployment of the Helix Curriculum.

A new, inclusive database was created to gather and evaluate student related data previously housed in admissions, academic, affairs, clinical services, and the dean's office. This comprehensive database now provides powerful information, allowing for more timely, evidence based decision-making from application through graduation. It was agreed that the holistic applicant characteristics currently being evaluated for admissions decisions be carefully 
examined in order to admit students with the highest probability of success in this new curriculum, with its stronger emphasis on active, integrated learning.

As described above, effort was made to examine goals, specialized roles, and current organizational construct and to structure the process of curricular change to direct energy and resources for the greatest likelihood for success (Bolmen \& Gallo, 2011).

\section{Human Resource Frame}

Bolman and Deal's human resource frame helps an institution align individual and organizational needs, improves human resource management, and supports positive relational dynamics, including perceptions, attitudes, motivation, participation, training, respect for diversity, and job satisfaction, among others. (Bolman \& Deal, 2003, 1985; Gallos, 2006).

The school's 2007 update of vision, mission, and strategic plan was accomplished by broad based agreement, including input from numerous small group and large town hall discussions. Individuals from all stakeholder groups associated with the school were actively involved. (University of the Pacific Arthur A. Dugoni School of Dentistry Strategic Plan, 2007). The benefits of such inclusion are emphasized by Bland and colleagues who note that participation in major decisions is critical to creating the consensus and strong commitment necessary to implement and sustain change (Bland, et al., 2000).

Once stakeholders agreed on the educational concepts, consistent communication of planning, implementation progress, and early outcomes proved motivating. Strong, vocal leaders, at all levels of the organization, willing to champion the proposed curricular model and drive early implementation were instrumental change agents. Bland and colleagues report that such "A culture of collegial support and interpersonal bonding is associated with successful change" (Bland, et al.,2000). Continued focus on the school's core values of humanism, innovation, leadership and reflection contributed to a positive climate for change (University of the Pacific Arthur A. Dugoni School of Dentistry Strategic Plan, 2012). (Table 2)

The school's strategic plan included a commitment to develop faculty and staff to lead curricular change and nurture critical thinkers and lifelong learners (University of the Pacific Arthur A. Dugoni School of Dentistry Strategic Plan, 2012). Targeted faculty development was deemed critical to planning and implementation of meaningful curricular reform, an aspect of human resource management confirmed by Hendricson and colleagues (Hendricson, et al., 2007). Bolman and Deal similarly espouse the benefits of investing in human capital by providing learning and development opportunities (Bolman \& Deal, 2003, 1985). Localized staffing reorganization allowed for greater resources to be redirected towards faculty development and support, in alignment with the strategic plan.

Faculty development programs were created with a focus on pedagogical concepts, instructional design, assessment, technology, and leadership. Faculty and chairs were surveyed to determine specific priorities. Faculty were asked specifically what pedagogical areas they perceived greatest interest in improving. (Table 3) To coordinate growth opportunities in a more strategic and comprehensive way, the community voted to combine representation and budget commitment from the Dental Faculty Council, Department Chairs, and the Academic Dean's Office to create a highly synergistic Faculty Development Oversight Committee. The committee was charged to review developments in the art and science of dentistry, as well as dental education and teaching pedagogies, and to create a strategic plan for faculty development. 
Table 2

2011-12 Strategic Plan Update Survey - Question 3

\begin{tabular}{|c|c|c|c|c|c|c|}
\hline & $\begin{array}{l}\text { egic Plan ident } \\
\text { distinctive ide } \\
\text { re values? }\end{array}$ & $\begin{array}{l}\text { fies sev } \\
\text { ntity. I }\end{array}$ & $\begin{array}{l}\text { core val } \\
\text { ur opin }\end{array}$ & $\begin{array}{l}\text { that cha } \\
\text { how we }\end{array}$ & $\begin{array}{l}\text { terize our } \\
\text { loes the sc }\end{array}$ & $\begin{array}{l}\text { chool and } \\
\text { ool live up }\end{array}$ \\
\hline \# & Answer & $\begin{array}{l}\text { Min } \\
\text { Value }\end{array}$ & $\begin{array}{l}\text { Max } \\
\text { Value }\end{array}$ & $\begin{array}{l}\text { Average } \\
\text { Value }\end{array}$ & $\begin{array}{l}\text { Standard } \\
\text { Deviation }\end{array}$ & Responses \\
\hline 1 & Humanism & 1.00 & 5.00 & 3.88 & 1.00 & 112 \\
\hline 2 & Innovation & 1.00 & 5.00 & 3.50 & 0.84 & 112 \\
\hline 3 & Leadership & 1.00 & 5.00 & 3.73 & 0.96 & 112 \\
\hline 4 & Reflection & 1.00 & 5.00 & 3.13 & 0.93 & 112 \\
\hline 5 & Stewardship & 1.00 & 5.00 & 3.34 & 0.92 & 112 \\
\hline 6 & Collaboration & 1.00 & 5.00 & 3.12 & 1.00 & 112 \\
\hline 7 & Philanthropy & 2.00 & 5.00 & 3.66 & 0.91 & 112 \\
\hline
\end{tabular}

Table 3.

Faculty Development Survey

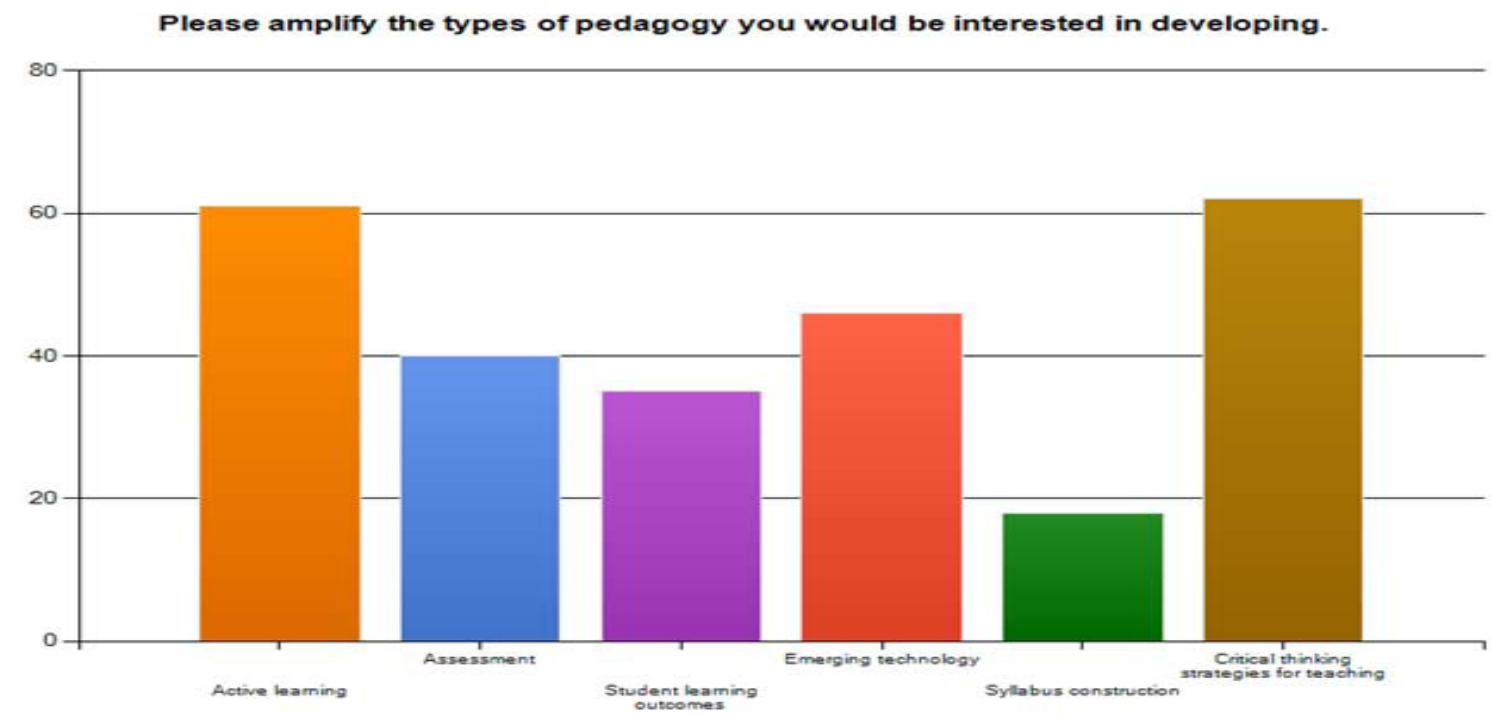

Source: Faculty Development Oversight Committee - Survey of Faculty Preferences Regarding Development - 2011 .

Through partnerships with the University's School of Education and Center for Teaching and Learning, increased focus on teaching methods, outcomes assessment, use of technology, and scholarly publication is being achieved. To-date, generous school development opportunities 
have supported faculty attainment of 20 Masters degrees in Business Administration; 43 Master's degrees in Education; 10 Doctoral degrees in Education; with 10 doctoral candidates in Education currently in progress.

In addition to intentionally planned faculty development and recognition, unanticipated opportunities for faculty collaboration and growth have occurred. Integrated case based seminars bring faculty from all disciplines together to present material and lead discussion. Participating faculty agreed that, not only does this collaborative teaching reduce silos, it has also increased personal translational knowledge (Hoover and Lyon, 2011). In the spirit of Bolman and Deals' human resource frame, aligning individual faculty development needs and organizational needs was imperative to building the capacity of both.

\section{Political Frame}

Boleman and deal's political frame considers the realistic process of making decisions and allocating resources in a context of finite resources, differing perspectives, and divergent interests. (Bolman \& Deal, 2003, 2008). This is particularly important in current times with so many Universities experiencing decreased funding support. Given the different personality types and operational styles of any school's stakeholders, consensus around how to achieve curricular improvements, or whether improvement is even necessary, remains an ongoing discussion (MTBI Basics, 2011). Restructuring of traditional curricular formats, courses, and departments brought apprehension to some. Adding to this challenge was the fact that the school's historic traditional curriculum continued, by most accounts, to graduate competent new general dentists. Some adhered to the idea, "if it isn't broken - why fix it".

Faculty buy-in and support of any curricular change is critical to success. To surmount anxieties as processes move forward, farther from the status quo, Bolman and Deal stress the importance of focusing on clear and consistent agreed upon goals (Bolman \& Deal, 1997).

A process of ongoing curricular improvement was grounded in the school's mission statement and strategic plan (University of the Pacific Arthur A. Dugoni School of Dentistry Strategic Plan and Vision and Mission Statement). It might be argued that, in addition to the school's institutional mission and vision, the American Dental Education Association's Competencies for the New General Dentist provided added inspiration and urgency (American Dental Education Association, 2008). Finally, the goals for developing and implementing the new Helix curriculum were in strong concordance with the University's aspirations. (Table 4: University of the Pacific Arthur A. Dugoni School of Dentistry Vision and Mission Statement).

With a consistent vision for the new curriculum established, the administration generously shared power and discretion with work groups. The process additionally benefited from a cadre of strong, respected faculty leaders capable of networking, supporting collaboration, and advocating for the Helix Curriculum initiatives.

As the Helix Curriculum became more integrated, the school's curriculum management system required significant revision. Content Experts were identified and charged with responsibility for specific subject matter currency, sequencing, assessment, and documentation. This agreement allowed for a heightened stakeholder focus on content and a reduced focus on course ownership. This change supported more fluid integration of content then the historic course or department driven focus allowed. Such integration is encouraged by researcher William Hendricson who suggests we reduce the traditional necessity for dental students to bounce between multiple, siloed courses, conducted independently, without coordination and, 
alternatively, consider ways "to limit a student's span of attention to no more than four courses at a time" (Hendricson, 2012).

Table 4

Relationship between university and dental school goals and core values

\begin{tabular}{|c|c|c|}
\hline $\begin{array}{l}\text { University } \\
\text { strategic goal }\end{array}$ & Dental School goal & $\begin{array}{l}\text { Dental School core } \\
\text { value }\end{array}$ \\
\hline $\begin{array}{l}\text { 1. Build the } \\
\text { strength, relevance, } \\
\text { and reputation of } \\
\text { Pacific's academic } \\
\text { programs. }\end{array}$ & $\begin{array}{l}\text { - Prepare oral healthcare providers for } \\
\text { scientifically-based practice; } \\
\text { - Define new standards for education } \\
\text { - Discover and disseminate knowledge } \\
\text { - Develop and promote policies addressing } \\
\text { the needs of society }\end{array}$ & $\begin{array}{l}\text { innovation, } \\
\text { leadership, } \\
\text { reflection, } \\
\text { collaboration }\end{array}$ \\
\hline $\begin{array}{l}\text { 2. Pursue new } \\
\text { student markets } \\
\text { that capitalize on } \\
\text { the strengths of } \\
\text { Pacific's academic } \\
\text { programs and } \\
\text { multiple locations. }\end{array}$ & $\begin{array}{l}\text { - } \\
\text { - Actualize individual potential } \\
\text { - Develop and promote policies addressing } \\
\text { the needs of society } \\
\text { - Discover and disseminate knowledge }\end{array}$ & $\begin{array}{l}\text { innovation, } \\
\text { leadership, } \\
\text { collaboration }\end{array}$ \\
\hline $\begin{array}{l}\text { 3. Prepare students } \\
\text { for tomorrow's } \\
\text { careers and } \\
\text { lifelong success. }\end{array}$ & $\begin{array}{l}\text { - Prepare oral healthcare providers for } \\
\text { scientifically-based practice } \\
\text { - Provide patient-centered care } \\
\text { - Discover and disseminate knowledge } \\
\text { - Actualize individual potential } \\
\text { - Develop and promote policies addressing } \\
\text { the needs of society }\end{array}$ & $\begin{array}{l}\text { humanism, } \\
\text { innovation, } \\
\text { leadership, } \\
\text { reflection, } \\
\text { stewardship, } \\
\text { collaboration }\end{array}$ \\
\hline $\begin{array}{l}\text { 4.Develop } \\
\text { organizational } \\
\text { capacities that } \\
\text { support Pacific's } \\
\text { mission }\end{array}$ & $\begin{array}{ll}\text { - } & \text { Actualize individual potential } \\
\text { - } & \text { Define new standards for education }\end{array}$ & $\begin{array}{l}\text { humanism, } \\
\text { stewardship, } \\
\text { philanthropy }\end{array}$ \\
\hline
\end{tabular}

Source: University of the Pacific School of Dentistry 2014 Accreditation Self-Study

In addition to sharing resources and empowering the architects of curricular change, the Office of Academic Affairs has consistently recognized and rewarded innovation and achievement. This operational style of setting and broadly sharing an agenda; bringing stakeholders together, developing logical networks and partnerships, supporting activities, and crediting participants with positive outcomes appears in keeping with best leadership and practices in the political frame (Bolman \& Deal, 1997).

\section{Symbolic Frame}


Bolman and Deal assert that "culture is the glue that holds an organization together and unites people around shared values and beliefs" (Bolman \& Deal, 2003). Rituals, ceremonies, stories, symbols, values and vision all contribute to a strong symbolic frame (Gallos, 2006). The dental school aspires to excellence and innovation in education, research, community service and patient care. Seven core values affirm this commitment and help shape the daily interactions of faculty, staff, and students: 1.) Humanism - dignity, integrity and responsibility, 2.) Innovation - willingness to take calculated risk, 3.) Leadership - modeling, inspiring and mobilizing, 4.) Reflection - using facts and outcomes for continuous improvement, 5.) Stewardship responsible use and management of resources, 6.) Collaboration - partnering for the common good, 7.) Philanthropy - investing time, talent and assets (University of the Pacific Arthur A. Dugoni School of Dentistry Core Values, n.d.)

Values clarification exercise preliminary to curricular changes confirmed the importance of these guiding principles and provided a platform from which to direct change. Stakeholders perceive humanism as emblematic of the school's learning environment, affirmed by its prominence in the 2007 strategic plan (University of the Pacific Arthur A. Dugoni School of Dentistry Strategic Plan, 2012; Morton, 2008, American Dental Association Commission on Dental Accreditation, 2013). Leadership is also a strongly held value, noted in the Strategic Plan as both a distinguishing feature; and a goal, implicit in the school's curriculum and culture (University of the Pacific Arthur A. Dugoni School of Dentistry Strategic Plan, 2012, Dugoni, 2002, Hammer \& Nadershahi, 2011). Core values informed and inspired this change initiative.

To emphasize and rally faculty around the curricular revision process, a symbolic logo representing the Dental Helix Curriculum was created by a representative focus group. (Figure 4) The logo brought clarity and reinforcement to the conceptual idea of curriculum organized into five strands with interconnectors. Chairs were asked to encourage use of this symbolism early and often.

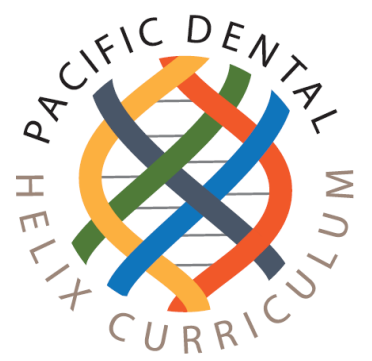

Figure 4. Dental Helix Curriculum logo.

Individual commitment and implementation is essential to the success of any initiative (Bolman \& Deal, 2003). In both symbolic and actual recognition of such personal investment, Promotion and Tenure guidelines were updated at the University level to include a greater emphasis on the scholarship of teaching and learning. To encourage and recognize creativity and advancement, an annual award for curricular innovation was created, the winner selected by school peers.

The symbolic frame reminds us to celebrate what we hope to achieve, and to create the symbols and ceremonies that inspire and build upon the values and culture of the organization. (Bolman \& Deal, 2003). 


\section{Conclusions}

Bolman and Deal's structural, human resource, political and symbolic constructs were, indeed, evident, and easily recognized in the institution examined, as described. Observation of these lenses, as both a window on the organization and a tool by which to navigate change, helped leaders better understand challenges and opportunities. Intentionally anticipating, considering, and strategically addressing stakeholder needs in each of these frames supported more efficient and authentic change. With the assistance of Bolman and Deal's organizational frames, among a number of change strategies, the school has been able to accomplish the majority of its curricular reform (Table 5).

Table 5

Development and Implementation Timeline for Curriculum Reform at the University of the Pacific Arthur A. Dugoni School of Dentistry

\begin{tabular}{|c|c|}
\hline Year & Action \\
\hline 2004 & Values clarification exercise \\
\hline 2005-06 & $\begin{array}{l}\text { Curriculum committee commitment to reform and initial schedule } \\
\text { adjustments to support integration planning for an Integrated Clinical }\end{array}$ \\
\hline \multicolumn{2}{|r|}{ J } \\
\hline & course (ICS II) \\
\hline 2006-07 & Strategic planning process \\
\hline $2007-08$ & Selection and training of content coordinators \\
\hline $2007-10$ & $\begin{array}{l}\text { Further planning and full implementation of the Integrated Clinical Sciences } \\
\text { strand (ICS I, II, and III) }\end{array}$ \\
\hline 2009 & Facilities study (Classroom of the Future) \\
\hline $2009-10$ & $\begin{array}{l}\text { Planning for Integrated Medical Sciences (IMS) courses and Personalized } \\
\text { Instructional Program (PIP) strand }\end{array}$ \\
\hline 2011 & Implementation of IMS course \\
\hline 2012 & Implementation of portions of Clinical Practice strand and pilot launch of the \\
\hline \multicolumn{2}{|r|}{ T } \\
\hline & strand \\
\hline $2011-13$ & Planning for the Integrated Preclinical Technique (IPT) strand \\
\hline 2013 & Implementation of the IPT strand \\
\hline 2014 & Move to new dental school facility in support of Helix curriculum goals \\
\hline
\end{tabular}

Source: Nadershahi N.A., et al. 2013

In planning this change initiative, the school carefully considered the challenging dynamics of the academy and developed strategies for purposefully managing these. At stake was the kind of enduring, positive change described by Bland and coauthors who evaluated a number of academic programs that had implemented broad curricular reform. They identified the 
following features associated with sustainable long-term success, many of which are also visible in Bolman and Deal's organizational frames (Bland, et al., 2000). (Table 6)

Table 6

Features Associated with Enduring Change, and Curriculum Outcomes

\section{Institutional Design Features}

Mission and goals. The goals of the initiative must match the institution's mission and goals.

History of change. Institutions that have histories of effective change are more likely to implement new innovations.

Cooperative climate. A culture of collegial support and interpersonal bonding is associated with successful change.

Organizational structure. Organizations that are highly hierarchical, compartmentalized, and operating in a bureaucratic structure are less successful at implementing change.

Political structure and policies. Successful change is associated with all sources of political strength (influence, policies, and funding), both internal and external, being shaped to support the desired innovation and existing or new policies being put in place to support the initiative.

Relationships with external environments. An understanding of community culture, expectations, and stability facilitates successful change. It is also important to improve and not jeopardize relations with professional accrediting bodies.

\section{Institutional Process Features}

Participation of members. Involvement of institutional members in all major decisions creates consensus and the needed commitment to implement and sustain the innovation.

Communication. Frequent and substantive communication is necessary for disseminating information about the innovation and change process, and creating and implementing desired change.

Leadership. Leaders with a vision of the desired outcomes and processes for reaching those outcomes are essential. Through the use of strategies such as the mobilization of external forces, coalition building, the promotion of action, consistent high-quality communication, and participative decision making, these individuals ensure that the innovation is accepted.

Human resource development. Diverse and repeated training is crucial to arm individuals for success in implementing the innovation.

Evaluation. Ongoing data collection is essential for evolutionary planning and implementation.

\section{Curriculum Process Features}

Curriculum features. A major curricular innovation must contain certain characteristics in order to be initiated. It must be viewed as meeting a perceived need, credible, bringing advantages to both students and faculty, having administrative support, having the involvement of influential people, 
having a participative governance process, and having a broad level of awareness, participation, and support.

Source: Bland, C et al. 2000

Some participants in this reform worried that successful change in select areas might result in undesired outcomes in others. Stakeholders wanted to feel that their financial and human resources would be used to a positive end. Recognition of Bolman and Deal's organizational frames helped this institution negotiate the challenges inherent in a major curricular reform initiative, and move towards constructive change and positive outcomes. Designing initiatives to support structural, human resource, political and symbolic perspectives was critical.

The authors believe that utilization of Bolman and Deal's reframing perspectives provided a helpful set of lenses through which to recognize the school's institutional strengths and potential barriers to change. With these in mind, strategies were developed to support and move major curricular reform initiatives forward. Actively operationalizing these strategies helped create a number of the processes recognized by the literature as important to successful change. These reframing approaches may prove helpful to other institutions going through like strategic plan implementation and curricular innovation.

\section{References}

American Dental Association Commission on Dental Accreditation (2012). Accreditation Standards for Dental Education Programs. Adopted October 2012. Retrieved on January 11, 2014 at: http://www.ada.org/115.aspx

American Dental Education Association. (2008). Competencies for the new general dentist. Retrieved January 11, 2014 from:

http://www.adea.org/about_adea/governance/Pages/Competencies-for-the-New-GeneralDentist.aspx

Behar-Horenstein, L.S. Critical thinking skills toolbox. American Dental Education Association. Retrieved January 11, 2014 from: http:/www.adea.org/adeacci/Resources/Critical-ThinkingSkills-Toolkit/Pages/default.aspx

Bertolami. C.N. (2001). Rationalizing the dental curriculum in light of current disease prevalence and patient demand for treatment: form vs. content. Journal of Dental Education, 6(8):725-735.

Bland, C.J., Starnaman, S., Harris, D., Henry, R. \& Hembroff, L. (2000) "No fear" curricular change: Monitoring curricular change in the W.K. Kellogg foundation's national initiative on community partnerships and health professional education. Academic Medicine, 75(6): 623-633. doi: 10.1097/00001888-200006000-00014

Bolman, L.G. \& Deal T.E. (1997). Reframing organizations. San Francisco, CA: Jossey-Bass.

Bolman, L.G. \& Deal, T.E. (2003) Reframing organizations: artistry, choice, and leadership. 3rd ed. San Francisco, CA: Jossey-Bass. 
Bolman, L.G. \& Deal, T.E. (1985). Modern approaches to understanding and managing organizations. San Francisco, CA: Jossey-Bass.

Dugoni, A. (2002). A dental school that serves the practicing profession. Journal of the California Dental Association, 10:763-8.

Facione, N.C. \& Facione, P.A. (2008). Critical thinking and clinical reasoning in the health sciences: A teaching anthology. Millbrae, CA: Insight Assessment /The California Academic Press.

Gallos, J.V. (2006). Reframing complexity: a four-dimensional approach to organizational diagnosis, development, and change. In: Gallos JV, ed. Organization development. San Francisco, CA: Jossey-Bass.

Haden, N.K., Andrieu, S.C., Chadwick, D.G., Chmar, J.E., Cole, J.R., George, M.C., Glickman, G.N., Glover, J.F., Goldberg, J.S., Hendricson, W.D., Meyerowitz, C., Neumann, L., Pyle, M., Tedesco, L.A., Valachovic, R.W., Weaver, R.G., Winder, R.L., Young, S.K. \& Kalkwarf, K.L. (2006). ADEA Commission On Change and Innovation in Dental Education, The dental education environment. Journal of Dental Education, 70: 1265-1270.

Haden, N.K., Hendricson, W.D., Kassenbaum D.K., Ranney, R.R., Weinstein, G., Anderson, E.L. \& Valechovic, R.W. (2010). Curriculum change in dental education, 2003-09. Journal of Dental Education, 74(5): 539-557.

Hammer, D.A. \& Nadershahi, N.A. (2011). Assessing the demand and preferred format of a student leadership development program at Pacific. Journal of Dental Education, 75:1044-1052.

Hendricson, W.D. (2012). Changes in educational methodologies in predoctoral dental education: finding the perfect intersection. Journal of Dental Education, 76:118-141.

Hendricson, W.D., Anderson, E., Andrieu, S.C., Chadwick, D.G., Cole, J.R., George, M.C., Glickman, G.N., Glover, J.F., Goldberg, J.S., Haden, N.K., Kalkwarf, K.L., Meyerowitz, C., Neumann, L.M., Pyle, M., Tedesco. L.A., Valachovic, R.W., Weaver, R.G., Winder, R.L. \& Young, K. (2007). Does faculty development enhance teaching effectiveness? J Journal of Dental Education, 71(12):1513-1533.

Hoover, T.E., Lyon, L.J. (2011). Collateral opportunity for increased faculty collaboration and development through a mentored critical thinking and writing exercise in a dental school curriculum. Journal of the Scholarship of Teaching and Learning, 11(2): 52 - 63.

Irby, D.M. (1994). What clinical teachers in medicine need to know. Academic Medicine, 69(5): 333-342. doi:10.1097/00001888-199405000-00003

Morton, N.A. (2008). Benefits of a humanistic education: a student perspective. Journal of Dental Education, 72(1): 45-7. 
The Myers Briggs Foundation. MTBI Basics. Retrieved on January 11, 2014 at:

http://www.myersbriggs.org/my-mbti-personality-type/mbti-basics/

Stake, R. E. (1995). The art of case study research. Thousand Oaks, CA: Sage Publications.

University of the Pacific. Core Values. Retrieved on April 2, 2011 at:

http://www.dental.pacific.edu/The_Dugoni_Experience/Core_Values.html

University of the Pacific. Mission and Values. Retrieved on March 6, 2011 at:

http://www.pacific.edu/Administration/Board-of-Regents/Mission-and-Values.html

University of the Pacific Arthur A. Dugoni School of Dentistry. Strategic plan; June 12, 2007. Retrieved January 11, 2014 from: http://www.dental.pacific.edu/Strategic_Plan.html

University of the Pacific Arthur A. Dugoni School of Dentistry. Vision and Mission Statement. Retrieved on January 11, 2014 at:

http://www.dental.pacific.edu/The_Dugoni_Experience/Vision_and_Mission_Statement.html

University of the Pacific Arthur A. Dugoni School of Dentistry, School initiatives: Pacific dental helix curriculum. Retrieved August 25, 2011 from:

http://www.dental.pacific.edu/School_Initiatives/Pacific_Dental_Helix_Curriculum.html. 